\title{
DRIS Norms for grafted and non-grafted red bell pepper in semi arid climate conditions in a greenhouse
}

\author{
Esteban Sánchez ${ }^{1}$; Juan Manuel Soto-Parra²; Pablo Preciado-Rangel ${ }^{3}$; Alfonso Llanderal ${ }^{4}$; María Teresa Lao ${ }^{4}$ \\ ${ }^{1}$ Centro de Investigación en Alimentación y Desarrollo A.C. Delicias, Chihuahua. Mexico; ${ }^{2}$ Facultad de Ciencias Agrotecnológicas, Universidad \\ Autónoma de Chihuahua, Chihuahua, México; ${ }^{3}$ Instituto Tecnológico de Torreón, Torreón, Coahuila, México; ${ }^{4}$ Agronomy Department of \\ Higher Engineering School, University of Almeria, Agrifood Campus of International Excellence ceiA3, Ctra. Sacramento s/n, La Cañada \\ de San Urbano, Almería, Spain; mtlao@ual.es (corresponding author)
}

\begin{abstract}
The objective of this study was to compute and compare DRIS norms for grafted and non-grafted red bell pepper crops grown in semi arid climate conditions. DRIS norms were computed with 84 samples of first young mature leaves collected during developed stage. The experiment had a completely randomized block design, and the values obtained for each plant and each variable were considered as independent replicates. Thirty-two DRIS norms nutrient ratios and coefficients of variation (CV) were computed from $\mathrm{N}, \mathrm{P}, \mathrm{K}, \mathrm{Ca}, \mathrm{Mg}$, $\mathrm{Fe}, \mathrm{Cu}, \mathrm{Zn}$ and $\mathrm{Mn}$ analytical results. The ratios $\mathrm{P} / \mathrm{N}$ and $\mathrm{K} / \mathrm{N}$ in grafted and non-grafted pepper plants, showed low $\mathrm{CV}$ and therefore may play a fundamental role in crop production according with the DRIS norms calculated, since as light modification in the nutrient concentration led to a significant change in the nutritional balance. In conclusion, DRIS norms are sensitive for grafted and non-grafted plants. This work may signify an improvement in the nutritional diagnosis of grafted and non-grafted red bell pepper in semi arid climate conditions under a shaded greenhouse.
\end{abstract}

Keywords: Capsicum annuum, Diagnostic and Recommendation Integrated System, foliar diagnostic, leaf analysis, nutrient ratio, macronutrients.

\section{RESUMO}

Normas DRIS para pimentão vermelho com e sem enxerto em condicões semiáridas em casa de vegetação

O objetivo desse estudo foi avaliar e comparar as normas DRIS para o cultivo de pimentão vermelho com e sem enxerto, cultivado em condicões semi-áridas. As normas DRIS foram obtidas com 84 amostras de folhas recentemente amadurecidas, considerando o período de desenvolvimento da cultura. O delineamento experimental foi por blocos completamente ao acaso, e os valores obtidos de cada planta e cada variável foram considerados como réplica independente. Dos resultados analíticos de N, P, K, Ca, Mg, Fe, Cu, Zn e $\mathrm{Mn}$ foram computados trinta e duas normas Dris e seu coeficiente de variação $(\mathrm{CV})$. As quantidades ou proporções de $\mathrm{P} / \mathrm{N}$ e K/N em plantas de pimentão com e sem enxerto mostraran baixos $\mathrm{CV}$ e, por tanto, de acordo com as normas DRIS, têm função fundamental no desenvolvimento da cultura, devido ao fato que uma pequena modificação pode ocasionar variação significativa no balanço nutricional da planta. Concluindo, as normas DRIS são sensíveis ao enxerto em plantas. Este trabalho pode significar melhoria significativa na diagnose nutricional do pimentão vermelho, com e sem enxerto, em condições semiáridas em casa de vegetação sob sombra.

Palavras-chave: Capsicum annuum, análise foliar, diagnóstico foliar, quantidade de nutrientes, macronutrientes.

\section{Received on August 10, 2017; accepted on August 7, 2018}

$\mathrm{R}$ ed pepper is a vegetable of extraordinary economic and social importance, as it is one of the most important vegetable crops in the world, with a production area of 4,537,088 ha (FAOSTAT, 2016). From the point of view of health, red pepper has high content of provitamin A, due to the high concentrations of $\beta$-carotene and $\beta$-cryptoxanthin, anticancer compounds linked with oxygenated carotenoids (xanthophylls) and anti-ulcer properties (Mínguez-Mosquera \& HorneroMéndez, 1993).

Alkaline-calcareous soils, low organic matter content associated with nutrient deficiency in intensive crops and unbalanced fertilizer supply, prevail in many arid and semi arid regions of the world where red pepper is grown (Rashid et al., 2002). Also, the persistent exploitation of the soil, monoculture and the intensification of production processes, leads to the development of soil diseases. Bell pepper (Capsicum annuum) is very susceptible to nutritional disorders (Nabi et al., 2006), so it is important to generate information about these nutritional disorders and their impact on productivity and quality. This, together with the abiotic stresses, mainly salinity, suboptimal temperatures and water stress, can induce the appearance of physiopathies in the pepper such as blossom-end rot (BER) and cracking, inducing vegetal senescence and decreasing not only production, but also the quality of the product (Nabi et al., 2006).

To alleviate these problems the grafting technique has been introduced. Chávez-Mendoza et al. (2015) found that fruits obtained from grafted plants increased $\beta$-carotene and vitamin $\mathrm{C}$ concentrations and improved the antioxidant capacity, but had no influence on total phenol 
or lycopene contents.

Nevertheless, some studies have reported differences in nutrient composition in leaves of pepper between grafted and non-grafted plants (SánchezTorres et al., 2016). One of the most used techniques in nutrient diagnosis is the Diagnosis and Recommendation Integrated System (DRIS) which consists of a dual relationship between a pair of nutrients in leaves $(\mathrm{N} / \mathrm{P}, \mathrm{P} / \mathrm{N}$, $\mathrm{N} / \mathrm{K}, \mathrm{K} / \mathrm{N}$, etc.) and comparisons between series of nutrient indices (Abd El-Rheemet al., 2012; Llanderal, 2017). DRIS indices enable the evaluation of nutritional balance of a crop, ranking nutrient levels in relative order; negative results (below zero) mean nutrient deficiency, and positive results indicate nutrient excess (Beaufils, 1973). The calculation of DRIS index depends on the establishment of reference norms.

DRIS norms consist of the mean, variance and coefficient of variation of the dual ratio between nutrients $(\mathrm{N} / \mathrm{P}$, $\mathrm{P} / \mathrm{N}, \mathrm{N} / \mathrm{K}, \mathrm{K} / \mathrm{N}$, etc.) obtained from a crop reference population that shows a high yield population (Beaufils, 1973). The data bank to compose DRIS norms is composed by the highest crop yield and chemical analysis of leaf tissue. The method to select the form of ratio for a pair of nutrients to be used in DRIS calculation is described by Walworth \& Sumner (1987) and Nick (1998).

Current information concerning red bell pepper DRIS norms in this area is limited. Therefore, we conducted this experiment in order to compute and compare DRIS norms for grafted and non-grafted red bell pepper crops grown under shaded greenhouse in semi arid climate conditions.

\section{MATERIAL AND METHODS}

This study was performed with the data from experimental crops obtained in Delicias (Chihuahua, Mexico) during spring-summer growing season. Climatic parameters outside the shaded greenhouse were provided by the agro-climatic station of National Water Commission (CONAGUA, Mexico). During spring-summer growing season, maximum and minimum temperature ranged from 28 to $10^{\circ} \mathrm{C}$. Maximum and minimum relative humidity $(\mathrm{RH})$ ranged from $80 \%$ to $45 \%$, and global radiation ranged from 5.2 to $8.9 \mathrm{kWh}$ $\mathrm{m}^{-2}$. A sandy-clay soil was used with the following composition: $50.17 \mathrm{ppm}$ of $\mathrm{N}$-inorganic, $64.14 \mathrm{ppm}$ of $\mathrm{P}, 32.5 \mathrm{meq}$ $100 \mathrm{~g}^{-1}$ of CEC, electrical conductivity $0.84 \mathrm{dS} \mathrm{m}^{-1}, 1.68 \%$ of organic matter content and $\mathrm{pH} 7.72$.

The experiment was carried out in a shaded greenhouse. Red bell pepper cv. "Fascinato" was evaluated. Plants were grafted on cultivar "Terrano" as rootstock (Syngenta Seed, Houston, TX, USA). The crop was grown with a planting density of 2 plants $\mathrm{m}^{-2}$ and fertigated with $3 \mathrm{~L} \mathrm{~h}^{-1}$ drippers. Spacing between plants was $0.5 \mathrm{~m}$ and between rows was $1 \mathrm{~m}$. Fertilization used during plant growth was carried out with the fertilizers: $\mathrm{NH}_{4} \mathrm{NO}_{3}\left(50 \mathrm{~g} \mathrm{~m}^{-2}\right)$, UAN32 (Urea Ammonium Nitrate Solution, $16 \%, 8 \%, 8 \% \mathrm{~N})\left(38 \mathrm{~g} \mathrm{~m}^{-2}\right), 5-30-00(56$ $\left.\mathrm{g} \mathrm{m}^{-2}\right), \mathrm{KNO}_{3}\left(45 \mathrm{~g} \mathrm{~m}^{-2}\right), \mathrm{Ca}\left(\mathrm{NO}_{3}\right)_{2}(162$ $\left.\mathrm{g} \mathrm{m}^{-2}\right), \mathrm{K}_{2} \mathrm{SO}_{4}\left(201 \mathrm{~g} \mathrm{~m}^{-2}\right)$ and $\mathrm{Mg}_{2} \mathrm{SO}_{4}$ $\left(108 \mathrm{~g} \mathrm{~m}^{-2}\right)$. Fertilizers were applied via fertigation every two days. Selection of the reference population is an important factor for the effectiveness and success of DRIS. Yield in the reference plots was in the range of 3.32 to $8.38 \mathrm{~kg} \mathrm{~m}^{-2}$. This was acceptable for production in this area with a mean yield of $5.54 \mathrm{~kg}$ $\mathrm{m}^{-2}$ (Sánchez et al., 2015). The reference group presented a normal distribution as recommended by Walworth \& Sumner (1987).

Database consisted of 84 samples. Leaf samples were composed of 15-30 healthy and fully developed leaves obtained from various plants. In laboratory, leaves were washed, and petioles disengaged. Samples were dried in an air-forced drying oven at $70^{\circ} \mathrm{C}$ for 24 hours, until constant weight was attained. Then, they were pulverized and sifted through an 80 micron mesh sieve and homogenized (Ministry of Agriculture and Fishing, 1994). Lastly, they were preserved in airtight polyvinyl chloride (PVC) containers, sealed with paraffin and stored in a dark, dry place. Each sample was divided into two subsamples, one was mineralized by the dry way method (Ruiz et al., 1999) and used to determine total $\mathrm{P}$ concentration by the ammonium molybdate method (Hogue et al., 1970), and total potassium $(\mathrm{K})$, calcium $(\mathrm{Ca})$, magnesium $(\mathrm{Mg})$, iron $(\mathrm{Fe})$, zinc $(\mathrm{Zn})$, copper $(\mathrm{Cu})$ and manganese $(\mathrm{Mn})$. Concentrations were determined by atomic absorption spectrometry (Ministry of Agriculture and Fishing, 1994). The other subsample was used to directly determine total $\mathrm{N}$ concentration by Kjeldahl digestion procedure (Ministry of Agriculture and Fishing, 1994).

To choose the ratio order of nutrients, the criteria proposed by Nick (1998) termed "R value" was selected. This consists of the calculation of the correlation coefficient (r) among productivity values obtained along with the relationships between pairs of nutrients, either in inverse or direct order. The order of the relationship that presents the largest absolute value of the coefficient of correlation ( $\mathrm{r}$ ) is selected:

If: $\mathrm{rA} / \mathrm{B}>\mathrm{rB} / \mathrm{A}$ then: relationship in the norm $=A / B$

If: $\mathrm{r} A / \mathrm{B}<\mathrm{r} B / \mathrm{A}$ then: relationship in the norm $=\mathrm{B} / \mathrm{A}$

Where $|\mathrm{r} \mathrm{A} / \mathrm{B}|$ is the absolute value of the correlation coefficient between productivity, and $\mathrm{A} / \mathrm{B}$ is the ratio among concentrations of nutrients $A$ and $\mathrm{B}$ of the population; $|\mathrm{r} \mathrm{B} / \mathrm{A}|$ and $\mathrm{B} / \mathrm{A}$ are the same as above for nutrients $\mathrm{B}$ and $\mathrm{A}$ in inverse order. The order of the relationship that presents the largest absolute value of the correlation coefficient (r) is selected. In the selection of the ratio order only database of harvesting was used.

The experiment had a completely randomized block design, and the values obtained for each plant and each variable were considered as independent replicates. Analysis of variance (ANOVA) and the least significant difference $(\mathrm{LSD})$ tests $(\mathrm{P}<0.05)$ were used to assess the differences between grafted and non-grafted. All statistical analyses were performed using Statgraphics Plus Software (version 5.1.).

\section{RESULTS AND DISCUSSION}

\section{Mineral composition}

Recent studies show that the rootstock 
induces changes in the nutritional status of the graft (Charlo et al., 2012). So, generating knowledge concerning the rootstock and graft relationship could be useful to help identify root systems that are tolerant to soil deficiencies or toxic to certain nutrients. Moreover, this would help us to develop specific fertilization programs for rootstockgraft combination.

The concentration gradient of macro and micronutrients in relation to the studied organs was greater to lesser: leaf $>$ peduncle $>$ fruit, except for $\mathrm{P}$ (Table 1). There were no significant differences in the concentration of all nutrients studied in fruits and peduncle. In the case of leaves, there were only significant differences in $\mathrm{Mn}$ and $\mathrm{Mg}$ concentration with the highest values in grafted plants (Table 1).

Previous studies by Ruiz et al. (1997) indicate that the response of some macronutrients, such as $\mathrm{K}, \mathrm{Ca}$, $\mathrm{Mg}, \mathrm{P}$ and $\mathrm{S}$, was mainly homogeneous. Rouphael et al. (2008) reported that total and commercial yields in miniwatermelons were $115 \%$ and $61 \%$ higher respectively in grafted plants compared to non-grafted plants. The concentration of $\mathrm{N}, \mathrm{K}$ and $\mathrm{Mg}$ in miniwatermelons leaves was elevated in 7.4, 25.6 and $38.8 \%$, respectively, in grafted plants compared to non-grafted plants.

Differences in nutrient concentration between non-grafted and grafted pepper plants were due to the effect of the rootstock-graft interaction (Table 1).
Ruiz et al. (1996) reported that the use of rootstocks can improve some morphological and/or physiological characteristics to increase soil nutrient uptake and translocation to graft leaves. In other studies, on grafted cherry, nutrient levels were less affected by the rootstock used (Neilsen \& Kappel, 1996).

Data obtained in the present work are in agreement with previous publications, which indicate the influence that genetic characteristics and vigour of the graft exert on mineral content of the leaf, since few nutrients are affected by the rootstock (Brown et al., 1994). The macronutrients more affected by the rootstock/graft interaction were: $\mathrm{K}, \mathrm{Ca}$, and $\mathrm{Mg}$; while for micronutrients were: $\mathrm{Fe}, \mathrm{Cu}, \mathrm{Zn}$ and $\mathrm{Mn}$. These results allow a selection of the rootstocks/variety more adapted or efficient in nutrient uptake. This efficiency could be attributed to the varieties grafted on the "Terrano" rootstock.

\section{Development of dris norms}

Currently, there are no specific DRIS norms for red bell pepper. The norms derived from this work have been generated from a representative population variability under semi arid climate conditions where this culture is widely developed. Means, coefficients of variation and correlation coefficients of macronutrient ratios of the reference for 2 populations (grafted and nongrafted red bell pepper) are shown in Table 2. Values in bold correspond to the ratios among selected nutrients. The common coefficients selected for grafted and non-grafted red bell pepper populations are $\mathrm{P} / \mathrm{K}, \mathrm{K} / \mathrm{N}, \mathrm{Ca} / \mathrm{N}, \mathrm{Ca} / \mathrm{P}$, $\mathrm{Ca} / \mathrm{K}, \mathrm{Mg} / \mathrm{Ca}, \mathrm{Mg} / \mathrm{Fe}, \mathrm{Fe} / \mathrm{N}, \mathrm{Fe} / \mathrm{K}, \mathrm{Fe} /$ $\mathrm{Zn}, \mathrm{Cu} / \mathrm{N}, \mathrm{Cu} / \mathrm{Fe}, \mathrm{Cu} / \mathrm{Mn}, \mathrm{Zn} / \mathrm{N}, \mathrm{Zn} / \mathrm{Mn}$ and $\mathrm{Mn} / \mathrm{Ca}$.

It is worth noting that some of the relationships among the nutrients showed a lower relationship between the ratio and each pair of nutrients and fruit productivity. Only the relationships N/ $\mathrm{Mn}, \mathrm{K} / \mathrm{N}, \mathrm{K} / \mathrm{Zn}, \mathrm{Ca} / \mathrm{N}, \mathrm{Ca} / \mathrm{P}, \mathrm{Ca} / \mathrm{K}$ and $\mathrm{Mg} / \mathrm{Ca}, \mathrm{Mg} / \mathrm{Fe}, \mathrm{Mg} / \mathrm{Zn}, \mathrm{Fe} / \mathrm{N}, \mathrm{Fe} / \mathrm{K}$, $\mathrm{Cu} / \mathrm{N}, \mathrm{Cu} / \mathrm{P}, \mathrm{Cu} / \mathrm{K}, \mathrm{Zn} / \mathrm{P}, \mathrm{Zn} / \mathrm{Mn}, \mathrm{Mn} /$ $\mathrm{Fe}$ in grafted plants and $\mathrm{P} / \mathrm{Mn}, \mathrm{K} / \mathrm{Mn}$, $\mathrm{Mg} / \mathrm{K}, \mathrm{Fe} / \mathrm{Mn}, \mathrm{Zn} / \mathrm{Mn}, \mathrm{Mn} / \mathrm{N}, \mathrm{Mn} / \mathrm{Ca}$ in non-grafted plants were greater than 0.30 . In the other cases, the choice of the relationship was accomplishment using a very low correlation coefficient.

Variability of DRIS norms (CV) within grafted and non-grafted plants is attributable to the varietal ability in uptake and nutrient use efficiency in the plant being higher in grafted plants (Velasco-Alvarado, 2016). Comparing $\mathrm{CV}$ of grafted and non-grafted plants with other authors, it is important to note that $\mathrm{CV}$ of the different ratios were lower than the $\mathrm{CV}$ proposed by Abd El-Rheem et al. (2012) which ranged from 13 to $126 \%$. A lower value in $\mathrm{CV}$ from the norms obtained with the DRIS technique means that a slight modification in nutrient concentration leads to a great change in the nutritional balance as proposed by Franco-Hermida

Table 1. Nutrient concentrations ( $\mathrm{g} \mathrm{kg}^{-1}$ dry matter) in fruit, leaf and peduncle in grafted and non-grafted red bell pepper plants. Delicias, Chihuahua, Mexico, CIAD, 2012.

\begin{tabular}{|c|c|c|c|c|c|c|}
\hline \multirow{2}{*}{ Nutrient } & \multicolumn{2}{|c|}{ Fruit } & \multicolumn{2}{|c|}{ Leaf } & \multicolumn{2}{|c|}{ Peduncle } \\
\hline & Grafted & Non-grafted & Grafted & Non-grafted & Grafted & Non-grafted \\
\hline $\mathbf{N}$ & $2.05 \pm 0.30 \mathrm{a}$ & $2.15 \pm 0.34 \mathrm{a}$ & $3.85 \pm 0.33 \mathrm{a}$ & $3.85 \pm 0.37 \mathrm{a}$ & $3.05 \pm 0.86 \mathrm{a}$ & $3.11 \pm 0.92 \mathrm{a}$ \\
\hline $\mathbf{P}$ & $0.23 \pm 0.06 \mathrm{a}$ & $0.24 \pm 0.07 \mathrm{a}$ & $0.14 \pm 0.04 \mathrm{a}$ & $0.12 \pm 0.02 \mathrm{a}$ & $0.18 \pm 0.06 \mathrm{a}$ & $0.17 \pm 0.05 \mathrm{a}$ \\
\hline $\mathbf{K}$ & $3.70 \pm 0.26 \mathrm{a}$ & $3.73 \pm 0.18 \mathrm{a}$ & $4.68 \pm 0.15 \mathrm{a}$ & $4.65 \pm 0.13 \mathrm{a}$ & $4.38 \pm 0.16 \mathrm{a}$ & $4.30 \pm 0.25 \mathrm{a}$ \\
\hline $\mathbf{C a}$ & $0.21 \pm 0.11 \mathrm{a}$ & $0.27 \pm 0.15 \mathrm{a}$ & $2.03 \pm 0.40 \mathrm{a}$ & $2.17 \pm 0.50 \mathrm{a}$ & $0.41 \pm 0.29 \mathrm{a}$ & $0.52 \pm 0.71 \mathrm{a}$ \\
\hline Mg & $0.57 \pm 0.08 \mathrm{a}$ & $0.57 \pm 0.07 \mathrm{a}$ & $1.95 \pm 0.14 \mathrm{a}$ & $1.64 \pm 0.12 b$ & $0.64 \pm 0.09 \mathrm{a}$ & $0.59 \pm 0.15 \mathrm{a}$ \\
\hline $\mathbf{F e}$ & $0.93 \pm 0.30 \mathrm{a}$ & $0.76 \pm 0.20 \mathrm{a}$ & $4.65 \pm 1.06 \mathrm{a}$ & $4.49 \pm 0.66 \mathrm{a}$ & $1.31 \pm 0.44 \mathrm{a}$ & $1.18 \pm 0.40 \mathrm{a}$ \\
\hline $\mathrm{Cu}$ & $0.18 \pm 0.04 \mathrm{a}$ & $0.19 \pm 0.09 \mathrm{a}$ & $1.40 \pm 0.74 \mathrm{a}$ & $1.19 \pm 0.63 \mathrm{a}$ & $0.27 \pm 0.14 \mathrm{a}$ & $0.28 \pm 0.25 \mathrm{a}$ \\
\hline $\mathbf{Z n}$ & $0.39 \pm 0.08 \mathrm{a}$ & $0.41 \pm 0.06 \mathrm{a}$ & $2.05 \pm 0.29 \mathrm{a}$ & $2.02 \pm 0.35 \mathrm{a}$ & $0.45 \pm 0.06 \mathrm{a}$ & $0.42 \pm 0.10 \mathrm{a}$ \\
\hline $\mathrm{Mn}$ & $0.14 \pm 0.02 \mathrm{a}$ & $0.13 \pm 0.02 \mathrm{a}$ & $1.99 \pm 0.35 \mathrm{a}$ & $1.40 \pm 0.20 \mathrm{~b}$ & $0.17 \pm 0.04 \mathrm{a}$ & $0.15 \pm 0.04 \mathrm{a}$ \\
\hline
\end{tabular}

*Means with different letters in the same column indicate significant differences between treatments using LSD test at $\mathrm{P} \leq 0.05$. 
Table 2. DRIS norms (mean, coefficient of variation and correlation coefficient) peduncle in grafted and non-grafted red bell pepper plants. Delicias, Chihuahua, Mexico, CIAD, 2012.

\begin{tabular}{|c|c|c|c|c|c|c|c|c|c|}
\hline \multicolumn{5}{|c|}{ Grafted } & \multicolumn{5}{|c|}{ Non-grafted } \\
\hline Norms & Means & CV (\%) & $\mathbf{r}$ & & Norms & Means & CV (\%) & $\mathbf{r}$ & \\
\hline $\mathrm{N} / \mathrm{P}$ & 27.34 & 23.17 & 0.01 & ns & $\mathrm{N} / \mathrm{P}$ & 31.49 & 18.62 & -0.03 & ns \\
\hline $\mathrm{N} / \mathrm{K}$ & 0.82 & 8.97 & -0.47 & $*$ & $\mathrm{~N} / \mathrm{K}$ & 0.83 & 9.98 & -0.06 & ns \\
\hline $\mathrm{N} / \mathrm{Ca}$ & 1.98 & 26.22 & -0.53 & $*$ & $\mathrm{~N} / \mathrm{Ca}$ & 1.86 & 23.91 & 0.02 & ns \\
\hline $\mathrm{N} / \mathrm{Mg}$ & 1.98 & 13.93 & -0.28 & $* *$ & $\mathrm{~N} / \mathrm{Mg}$ & 2.36 & 14.17 & 0.22 & ns \\
\hline $\mathrm{N} / \mathrm{Fe}$ & 0.88 & 28.09 & -0.57 & $*$ & $\mathrm{~N} / \mathrm{Fe}$ & 0.88 & 20.65 & 0.03 & ns \\
\hline $\mathrm{N} / \mathrm{Cu}$ & 4.05 & 71.12 & -0.22 & $* *$ & $\mathrm{~N} / \mathrm{Cu}$ & 4.61 & 67.96 & 0.02 & ns \\
\hline $\mathrm{N} / \mathrm{Zn}$ & 1.91 & 16.35 & -0.79 & $* *$ & $\mathrm{~N} / \mathrm{Zn}$ & 1.95 & 17.11 & 0.01 & ns \\
\hline N/Mn & 2.09 & 19.40 & -0.30 & $*$ & $\mathrm{~N} / \mathrm{Mn}$ & 2.64 & 23.05 & 0.47 & $* *$ \\
\hline $10 * \mathrm{P} / \mathrm{N}$ & 0.39 & 24.76 & 0.02 & ns & $10 * P / N$ & 0.33 & 19.42 & 0.04 & ns \\
\hline $10 * \mathrm{P} / \mathrm{K}$ & 0.32 & 22.90 & -0.20 & $\mathrm{~ns}$ & $10 * \mathrm{P} / \mathrm{K}$ & 0.27 & 17.96 & 0.02 & ns \\
\hline $10 * \mathrm{P} / \mathrm{Ca}$ & 0.77 & 38.87 & -0.38 & $*$ & $10 * \mathrm{P} / \mathrm{Ca}$ & 0.61 & 30.33 & 0.06 & ns \\
\hline $10 * \mathrm{P} / \mathrm{Mg}$ & 0.76 & 22.09 & -0.16 & $\mathrm{~ns}$ & $10 * \mathrm{P} / \mathrm{Mg}$ & 0.77 & 19.78 & 0.22 & ns \\
\hline $10 * \mathrm{P} / \mathrm{Fe}$ & 0.33 & 30.01 & -0.55 & $*$ & $10 * \mathrm{P} / \mathrm{Fe}$ & 0.29 & 24.75 & 0.09 & ns \\
\hline $10 * \mathrm{P} / \mathrm{Cu}$ & 1.59 & 89.57 & -0.21 & $\mathrm{~ns}$ & $10 * \mathrm{P} / \mathrm{Cu}$ & 1.55 & 77.02 & 0.05 & ns \\
\hline $10 * \mathrm{P} / \mathrm{Zn}$ & 0.74 & 29.82 & -0.43 & $* *$ & $10 * P / Z n$ & 0.64 & 26.70 & 0.05 & ns \\
\hline $10 * \mathrm{P} / \mathrm{Mn}$ & 0.80 & 30.84 & -0.21 & $\mathrm{~ns}$ & $10 * \mathrm{P} / \mathrm{Mn}$ & 0.87 & 29.69 & 0.39 & $* *$ \\
\hline $\mathrm{K} / \mathbf{N}$ & 1.23 & 8.48 & 0.49 & $* *$ & $\mathbf{K} / \mathbf{N}$ & 1.22 & 9.61 & 0.08 & ns \\
\hline $\mathbf{K} / \mathbf{P}$ & 33.22 & 21.27 & 0.21 & ns & $\mathrm{K} / \mathrm{P}$ & 38.17 & 17.94 & 0.01 & ns \\
\hline $\mathrm{K} / \mathrm{Ca}$ & 2.42 & 26.30 & -0.39 & $*$ & $\mathrm{~K} / \mathrm{Ca}$ & 2.25 & 22.56 & 0.03 & ns \\
\hline $\mathrm{K} / \mathrm{Mg}$ & 2.41 & 7.13 & 0.06 & ns & $\mathrm{K} / \mathrm{Mg}$ & 2.85 & 8.34 & 0.43 & $* *$ \\
\hline $\mathrm{K} / \mathrm{Fe}$ & 1.07 & 27.04 & -0.45 & $* *$ & $\mathrm{~K} / \mathrm{Fe}$ & 1.06 & 16.90 & 0.09 & ns \\
\hline $\mathrm{K} / \mathrm{Cu}$ & 4.89 & 68.70 & -0.16 & $\mathrm{~ns}$ & $\mathrm{~K} / \mathrm{Cu}$ & 5.54 & 66.15 & 0.04 & ns \\
\hline $\mathbf{K} / \mathbf{Z n}$ & 2.32 & 14.11 & -0.63 & $* *$ & $\mathrm{~K} / \mathrm{Zn}$ & 2.36 & 17.14 & 0.02 & ns \\
\hline $\mathrm{K} / \mathrm{Mn}$ & 2.54 & 16.47 & 0.09 & $\mathrm{~ns}$ & $\mathbf{K} / \mathbf{M n}$ & 3.19 & 19.23 & 0.58 & $*$ \\
\hline $\mathrm{Ca} / \mathrm{N}$ & 0.53 & 21.93 & 0.58 & $* *$ & $\mathrm{Ca} / \mathbf{N}$ & 0.57 & 25.62 & 0.10 & ns \\
\hline $\mathrm{Ca} / \mathbf{P}$ & 14.50 & 30.29 & 0.42 & $*$ & $\mathbf{C a} / \mathbf{P}$ & 17.97 & 32.60 & 0.08 & ns \\
\hline $\mathrm{Ca} / \mathrm{K}$ & 0.43 & 20.52 & 0.41 & $* *$ & $\mathrm{Ca} / \mathrm{K}$ & 0.47 & 24.29 & 0.05 & ns \\
\hline $\mathrm{Ca} / \mathrm{Mg}$ & 1.04 & 20.44 & 0.42 & $* *$ & $\mathrm{Ca} / \mathrm{Mg}$ & 1.33 & 24.55 & 0.15 & $\mathrm{~ns}$ \\
\hline $\mathrm{Ca} / \mathrm{Fe}$ & 0.46 & 26.98 & -0.13 & ns & $\mathrm{Ca} / \mathrm{Fe}$ & 0.49 & 27.63 & 0.15 & ns \\
\hline $\mathrm{Ca} / \mathrm{Cu}$ & 2.20 & 79.35 & 0.01 & $\mathrm{~ns}$ & $\mathrm{Ca} / \mathrm{Cu}$ & 2.60 & 62.46 & 0.04 & ns \\
\hline $\mathrm{Ca} / \mathrm{Zn}$ & 1.00 & 21.26 & 0.02 & ns & $\mathrm{Ca} / \mathrm{Zn}$ & 1.10 & 27.28 & 0.06 & ns \\
\hline $\mathrm{Ca} / \mathrm{Mn}$ & 1.12 & 30.13 & 0.21 & $\mathrm{~ns}$ & $\mathrm{Ca} / \mathrm{Mn}$ & 1.47 & 23.86 & 0.42 & $* *$ \\
\hline $\mathbf{M g} / \mathbf{N}$ & 0.51 & 12.10 & 0.29 & $*$ & $\mathbf{M g} / \mathbf{N}$ & 0.43 & 12.73 & -0.23 & ns \\
\hline $\mathbf{M g} / \mathbf{P}$ & 13.84 & 22.38 & 0.19 & ns & $\mathrm{Mg} / \mathrm{P}$ & 13.50 & 20.72 & -0.14 & ns \\
\hline $\mathbf{M g} / \mathbf{K}$ & 0.42 & 7.04 & -0.07 & ns & $\mathrm{Mg} / \mathrm{K}$ & 0.35 & 8.23 & -0.44 & $* *$ \\
\hline $\mathrm{Mg} / \mathrm{Ca}$ & 1.01 & 25.24 & -0.43 & $* *$ & $\mathrm{Mg} / \mathrm{Ca}$ & 0.79 & 21.91 & -0.17 & $* *$ \\
\hline $\mathbf{M g} / \mathrm{Fe}$ & 0.45 & 27.88 & 0.47 & $*$ & $\mathrm{Mg} / \mathrm{Fe}$ & 0.37 & 19.43 & -0.12 & ns \\
\hline $\mathrm{Mg} / \mathrm{Cu}$ & 2.08 & 73.12 & -0.16 & $\mathrm{~ns}$ & $\mathrm{Mg} / \mathrm{Cu}$ & 1.98 & 68.39 & -0.02 & ns \\
\hline Mg/Zn & 0.97 & 16.82 & -0.58 & $* *$ & $\mathrm{Mg} / \mathrm{Zn}$ & 0.83 & 17.32 & -0.21 & $\mathrm{~ns}$ \\
\hline $\mathrm{Mg} / \mathrm{Mn}$ & 1.06 & 19.65 & -0.11 & $\mathrm{~ns}$ & $\mathrm{Mg} / \mathrm{Mn}$ & 1.12 & 14.95 & 0.49 & $* *$ \\
\hline $\mathrm{Fe} / \mathbf{N}$ & 1.22 & 24.95 & 0.62 & $*$ & $\mathrm{Fe} / \mathrm{N}$ & 1.18 & 17.23 & -0.12 & ns \\
\hline $\mathrm{Fe} / \mathrm{P}$ & 32.71 & 30.15 & 0.50 & $*$ & $\mathrm{Fe} / \mathrm{P}$ & 36.78 & 22.00 & -0.10 & ns \\
\hline
\end{tabular}


Table 2. continuation

\begin{tabular}{|c|c|c|c|c|c|c|c|c|c|}
\hline \multicolumn{4}{|c|}{ Grafted } & & \multicolumn{5}{|c|}{ Non-grafted } \\
\hline Norms & Means & CV (\%) & $\mathbf{r}$ & & Norms & Means & CV (\%) & $\mathbf{r}$ & \\
\hline $\mathrm{Fe} / \mathrm{K}$ & 0.99 & 22.19 & 0.49 & $* *$ & $\mathrm{Fe} / \mathrm{K}$ & 0.97 & 15.11 & -0.18 & ns \\
\hline $\mathrm{Fe} / \mathrm{Ca}$ & 2.37 & 31.36 & 0.02 & $\mathrm{~ns}$ & $\mathrm{Fe} / \mathrm{Ca}$ & 2.16 & 23.86 & 0.05 & ns \\
\hline $\mathrm{Fe} / \mathrm{Mg}$ & 2.39 & 24.24 & 0.44 & $* *$ & $\mathrm{Fe} / \mathrm{Mg}$ & 2.75 & 16.53 & 0.02 & $\mathrm{~ns}$ \\
\hline $\mathrm{Fe} / \mathrm{Cu}$ & 4.76 & 72.71 & -0.04 & $\mathrm{~ns}$ & $\mathrm{Fe} / \mathrm{Cu}$ & 5.32 & 73.00 & 0.05 & $\mathrm{~ns}$ \\
\hline $\mathrm{Fe} / \mathrm{Zn}$ & 2.26 & 17.74 & 0.13 & ns & $\mathrm{Fe} / \mathrm{Zn}$ & 2.25 & 14.20 & -0.15 & ns \\
\hline $\mathrm{Fe} / \mathrm{Mn}$ & 2.48 & 22.01 & 0.38 & $* *$ & $\mathrm{Fe} / \mathrm{Mn}$ & 3.09 & 24.42 & 0.38 & $* *$ \\
\hline $\mathrm{Cu} / \mathrm{N}$ & 0.36 & 51.93 & 0.38 & $* *$ & $\mathrm{Cu} / \mathbf{N}$ & 0.31 & 55.09 & 0.03 & ns \\
\hline $\mathbf{C u} / \mathbf{P}$ & 9.82 & 54.72 & 0.35 & $*$ & $\mathrm{Cu} / \mathrm{P}$ & 9.86 & 56.12 & 0.04 & ns \\
\hline $\mathrm{Cu} / \mathrm{K}$ & 0.30 & 51.75 & 0.30 & $* *$ & $\mathrm{Cu} / \mathrm{K}$ & 0.25 & 52.08 & 0.03 & ns \\
\hline $\mathrm{Cu} / \mathrm{Ca}$ & 0.72 & 52.13 & 0.17 & ns & $\mathrm{Cu} / \mathrm{Ca}$ & 0.60 & 67.94 & 0.03 & ns \\
\hline $\mathrm{Cu} / \mathrm{Mg}$ & 0.73 & 55.71 & 0.29 & $* *$ & $\mathrm{Cu} / \mathrm{Mg}$ & 0.73 & 52.71 & 0.10 & $\mathrm{~ns}$ \\
\hline $\mathrm{Cu} / \mathrm{Fe}$ & 0.30 & 47.43 & 0.06 & ns & $\mathrm{Cu} / \mathrm{Fe}$ & 0.26 & 49.94 & 0.10 & ns \\
\hline $\mathrm{Cu} / \mathrm{Zn}$ & 0.67 & 49.22 & 0.14 & ns & $\mathrm{Cu} / \mathrm{Zn}$ & 0.58 & 52.11 & 0.06 & $\mathrm{~ns}$ \\
\hline $\mathrm{Cu} / \mathrm{Mn}$ & 0.73 & 51.58 & 0.22 & ns & $\mathrm{Cu} / \mathrm{Mn}$ & 0.82 & 58.94 & 0.24 & $* *$ \\
\hline $\mathrm{Zn} / \mathbf{N}$ & 0.54 & 17.80 & 0.76 & $*$ & $\mathrm{Zn} / \mathbf{N}$ & 0.53 & 18.48 & 0.02 & ns \\
\hline $\mathrm{Zn} / \mathbf{P}$ & 14.76 & 31.70 & 0.45 & $* *$ & $\mathrm{Zn} / \mathrm{P}$ & 16.81 & 29.78 & 0.01 & $\mathrm{~ns}$ \\
\hline $\mathrm{Zn} / \mathrm{K}$ & 0.44 & 15.05 & 0.61 & $* *$ & $\mathrm{Zn} / \mathrm{K}$ & 0.44 & 18.74 & -0.03 & ns \\
\hline $\mathrm{Zn} / \mathrm{Ca}$ & 1.05 & 22.94 & -0.01 & ns & $\mathrm{Zn} / \mathrm{Ca}$ & 0.97 & 26.12 & -0.02 & $\mathrm{~ns}$ \\
\hline $\mathrm{Zn} / \mathrm{Mg}$ & 1.06 & 17.17 & 0.54 & $* *$ & $\mathrm{Zn} / \mathrm{Mg}$ & 1.24 & 18.11 & 0.14 & $\mathrm{~ns}$ \\
\hline $\mathrm{Zn} / \mathrm{Fe}$ & 0.46 & 20.98 & -0.11 & ns & $\mathrm{Zn} / \mathrm{Fe}$ & 0.46 & 15.51 & 0.08 & $\mathrm{~ns}$ \\
\hline $\mathrm{Zn} / \mathrm{Cu}$ & 2.08 & 65.27 & -0.04 & ns & $\mathrm{Zn} / \mathbf{C u}$ & 2.37 & 70.21 & 0.07 & ns \\
\hline Zn/Mn & 1.11 & 17.09 & 0.41 & $* *$ & $\mathbf{Z n} / \mathbf{M n}$ & 1.38 & 20.91 & 0.51 & $*$ \\
\hline $\mathrm{Mn} / \mathrm{N}$ & 0.50 & 21.69 & 0.28 & $* *$ & $\mathbf{M n} / \mathbf{N}$ & 0.39 & 19.42 & -0.49 & * \\
\hline $\mathbf{M n} / \mathbf{P}$ & 13.47 & 28.22 & 0.22 & ns & $\mathrm{Mn} / \mathrm{P}$ & 12.50 & 29.57 & -0.35 & $* *$ \\
\hline $\mathbf{M n} / \mathbf{K}$ & 0.40 & 17.73 & 0.11 & ns & $\mathrm{Mn} / \mathrm{K}$ & 0.32 & 19.26 & -0.56 & $*$ \\
\hline $\mathbf{M n} / \mathbf{C a}$ & 1.00 & 39.47 & -0.23 & ns & $\mathrm{Mn} / \mathrm{Ca}$ & 0.72 & 25.94 & -0.48 & $*$ \\
\hline $\mathbf{M n} / \mathbf{M g}$ & 0.98 & 19.04 & 0.12 & ns & $\mathrm{Mn} / \mathrm{Mg}$ & 0.92 & 15.48 & -0.47 & $*$ \\
\hline $\mathrm{Mn} / \mathrm{Fe}$ & 0.43 & 25.24 & -0.43 & $* *$ & $\mathrm{Mn} / \mathrm{Fe}$ & 0.34 & 25.65 & -0.35 & $* *$ \\
\hline $\mathrm{Mn} / \mathrm{Cu}$ & 1.86 & 57.11 & -0.21 & ns & $\mathrm{Mn} / \mathrm{Cu}$ & 1.77 & 60.91 & -0.13 & $\mathrm{~ns}$ \\
\hline $\mathrm{Mn} / \mathrm{Zn}$ & 0.93 & 18.22 & -0.40 & $* *$ & $\mathrm{Mn} / \mathrm{Zn}$ & 0.76 & 20.78 & -0.48 & $*$ \\
\hline
\end{tabular}

The values in bold correspond to the ratios among nutrients selected. **indicates significant differences at $\mathrm{P} \leq 0.01$.

et al. (2013), Serra et al. (2012) and Llanderal et al. (2018). The ratios reported by Abd El-Rheem et al. (2012) in non-grafted sweet pepper were: $\mathrm{P} / \mathrm{N}$, $\mathrm{K} / \mathrm{N}, \mathrm{N} / \mathrm{Fe}, \mathrm{N} / \mathrm{Zn}, \mathrm{Mn} / \mathrm{N}, \mathrm{K} / \mathrm{P}, \mathrm{P} / \mathrm{Fe}$, $\mathrm{P} / \mathrm{Zn}, \mathrm{Mn} / \mathrm{P}, \mathrm{K} / \mathrm{Fe}, \mathrm{K} / \mathrm{Zn}, \mathrm{Mn} / \mathrm{K}, \mathrm{Fe} /$ $\mathrm{Zn}, \mathrm{Mn} / \mathrm{Fe}$ and $\mathrm{Mn} / \mathrm{Zn}$ with 10 and 4 ratios being in common for grafted and non-grafted peppers, respectively. The different ratios obtained by Abd ElRheem et al. (2012) could be related to the establishment of DRIS norms under different climatic conditions as proposed by Bangroo et al. (2010).

It is important to note that ratios of $\mathrm{K} / \mathrm{N}$ and $\mathrm{P} / \mathrm{N}$ in our experiment (grafted and non-grafted plants) (Table 2) showed lower coefficients of variation compared with values established by Abd El-Rheem et al. (2012). A suitable N/K relationship determines the equilibrium between the processes of growth and fruiting in the plant (Hernández et al., 2009). The importance of the relationship between $\mathrm{N} / \mathrm{K}$ in the fertilizer used on pepper has been proposed by Contreras et al. (2013). The relevance of the $\mathrm{P} / \mathrm{N}$ ratio could be due to great uptake of both elements in the fruit as proposed by Betancourt \& Pierre (2013) because of high metabolic requirement of the fruits.

In conclusion, DRIS norms presented in this paper could improve the nutritional diagnosis of red bell pepper. DRIS norms are sensitive to 
grafted and non-grafted plants. The DRIS norms developed in this study could be used in semi arid climate conditions under shaded greenhouse.

\section{REFERENCES}

ABD EL-RHEEM, KM; KHALED, SM; ZAGHOUL, M. 2012. Preliminary DRIS norms for evaluating nutritional status of sweet pepper crop. Advance in Agriculture and Biology 6: 661-664.

BANGROO, SA; BHAT, MI; ALI, T; AZIZ, MA; BHAT, MA; WANI, MA. 2010. Diagnosis and Recommendation Integrated System (DRIS) A Review. International Journal of Current Research 10: 84-97.

BEAUFILS, ER. 1973. Diagnosis and recommendation integrated system (DRIS). A general scheme of experimentation and calibration based on principles developed from research in plant nutrition. South Africa: University of Natal, Pietermaritzburg. 132p. (Soil Science Bulletin, 1)

BETANCOURT, P; PIERRE, F. 2013. Extracción de macronutrientes por el cultivo de tomate (Solanum lycopersicum Mill. var. "Alba") en casas de cultivo en Quíbor, estado Lara. Bioagro 25: 181-188.

BROWN, PH; ZHNAG, Q; FERGUSON, L. 1994. Influence of rootstock on nutrient acquisition by pistachio. Journal of Plant Nutrition 17: 1137-1148.

CHÁVEZ-MENDOZA, C; SÁNCHEZ, E; MUÑOZ-MARQUEZ, E; SIDA-ARREOLA, JP; FLORES-CORDOVA, MA. 2015. Bioactive compounds and antioxidant activity in different grafted varieties of bell pepper. Antioxidants 4: 427-446.

CONTRERAS, JI; EYMAR, E; LOPEZ, JG; LAO, MT; SEGURA, ML. 2013. Influences of nitrogen and potassium fertigation on nutrient uptake, production, and quality of pepper irrigated with desinfected urban wastewater. Communications in Soil Science and Plant Analysis 4: 767-775.

CHARLO, HCO; OLIVEIRA, SF; VARGAS, PF; CSTOLDI, R; BARBOSA, JC; BRAZ, LT. 2012. Accumulation of nutrients in sweet peppers cultivated in coconut fiber.
Horticultura Brasileira 30: 125-131.

FAOSTAT. 2016. Food and Agricultural Organization of the United Nations Statistical Database, Rome, Italy. http://faostat.fao.org.

FRANCO-HERMIDA, JJ; HENAO-TORO, MC; GUZMÁN, M; CABRERA, RI. 2013. Determining nutrient diagnostic norms for greenhouse roses. HortScience 48: 1403-1410.

HERNÁNDEZ, MI; SALGADO, JM; CHAILLOUX, M; MORENO, V; MOJENA, M. 2009. Relaciones nitrógeno-potasio en fertirriego para el cultivo protegido del tomate (Solanum lycopersicum L.) y su efecto en la acumulación de biomasa y extracción de nutrientes. Revista Cultivos Tropicales 30:71-78.

HOGUE, E; WILCOW, GE; CANTLIFFE, DJ. 1970. Effect of soil $P$ on phosphate fraction in tomato leaves. Journal of American Society for Horticultural Science 95: 174-176.

LLANDERAL, A. 2017. Study of diagnostic methods and evaluation of nutritional parameters in the intensive horticulture cropping systems as basis for a sustainable management of the fertigation. Almeria, E: Universidad de Almería. 173p (Ph.D. thesis).

LLANDERAL, A; LAO, MT; CONTRERAS, Ji; SEGURA, ML. 2018. Diagnosis and Recommendation integrated system norms and sufficiency ranges for tomato greenhouse in Mediterranean climate. HortScience 53: 479-482.

MÍNGUEZ-MOSQUERA, I; HORNEROMÉNDEZ, D. 1993. Separation and quantification of the carotenoid pigments in red peppers (Capsicum annuum L.), paprika, and oleoresin by reversed-phase HPLC. Journal of Agricultural and Food Chemistry 41: 1616-1620.

MINISTRY OF AGRICULTUREAND FISHING. 1994. Métodos oficiales de análisis. Tomo III. Madrid: Secretaria General Técnica. 532p.

NABI, G; RAFIQUE, E; SALIM, M. 2006. Boron nutrition of four sweet pepper cultivars grown in boron-deficient soil. Journal of Plant Nutrition 29:717-725.

NEILSEN, G. KAPPEL, F. 1996. Bing sweet cherry leaf nutrition is affected by rootstock. HortScience 31: 1169-1172.

NICK, JA. 1998. DRIS for coffee plants. (In Portuguese). Piracicaba: USP/ESALQ. 86p. (Ph.D. thesis).
RASHID, A; RAFIQUE, E; RYAN, J. 2002. Establishment and management of boron deficiency in field crops in Pakistan. A country report. In: GOLDBACH, HE; BROWN, PH; RERKASEM, B; THELLIER, M; WIMNER, MA; BELL, RW (eds). Boron in plant and animal nutrition. New York: Kluwer Academic Publisher. p. 339-348.

ROUPHAEL, Y; CARDARELLI, M; COLLA, G; REA, E. 2008. Yield, mineral composition, water relations, and water use efficiency of grafted mini-watermelon plants under deficit irrigation. HortScience 43: 730-736.

RUIZ, JM; BELAKBIR, A; ROMERO, L. 1996. Foliar level of phosphorus and its bioindicators in Cucumis melo grafted plants: a possible effect of rootstocks. Journal of Plant Physiology 149: 400-404.

RUIZ, JM; BELAKBIR, A; ROMERO, L. 1997. Response of plant yield and leaf pigments to saline conditions: effectiveness of different rootstocks in melon plants (Cucumis melo L.). Soil Science and Plant Nutrition 43: 855-862.

RUIZ, JM; MORENO, DA; ROMERO, L. 1999. Pyruvate kinase activity as an indicator of the level of $\mathrm{K}, \mathrm{Mg}$ and $\mathrm{Ca}$ in leaves and fruits of the cucumber: The role of potassium fertilization. Journal of Agricultural and Food Chemistry 47: 845-849.

SÁNCHEZ, E; TORRES-GONZÁLEZ, A; FLORES-CÓRDOVA, MA; PRECIADORANGEL, P; MÁRQUEZ-QUIROZ, C. 2015. Uso de porta injerto sobre el rendimiento, calidad del fruto y resistencia a Phytophthora capsici L. en pimiento morrón. Revista Nova Scientia 7: 227-244.

SÁNCHEZ-TORRES, P; RAIGÓN, MD; GAMMOUDI, N; GISBERT, C. 2016. Effects of grafting combinations on the nutritional composition of pepper fruit. Fruits 71: 249256.

SERRA, A.P; MARCHETTI, ME; ROJAS, EP; VITORINO, ACT. 2012. Beaufils ranges to assess the cotton nutrient status in the southern region of Mato Grosso. Revista Brasileira de Ciência do Solo 36: 171-182.

VELASCO-ALVARADO, MJ.2016. Composición mineral, biomasa y rendimiento en tomate (Solanum lycopersicum L.) injertado. Interciencia 41: 703-708.

WALWORTH, JL. SUMNER, ME. 1987. The diagnosis and recommendation integrated system (DRIS). In: Advances in Soil Science. New York: Springer. 